\title{
Short-Term and Long-Term Feedstock Bio Jet Fuel for Green Environment of Air Transport in Climate Change Awareness
}

\author{
Hazariah Mohd Noh ${ }^{1, a}$ and Nurul Ain Md Zulkifly ${ }^{2, b}$ \\ 1,2Universiti Kuala Lumpur Malaysian Institute Aviation Technology, \\ Lot 2891, Jalan Jenderam Hulu, Jenderam Hulu, 43800 Sepang, Selangor, Malaysia \\ ahazariah.mnoh@alumnos.upm.es, bnurulain@miat.unikl.edu.my
}

Keywords: aviation biofuel, biofuel feedstock, aviation climate change

\begin{abstract}
Air transportation and manageable cost is the key to determine the smooth running of the airlines. Today, the trend is changing with the environment generally and sustainability standards specifically. Responsibility towards environmental issues, in conjunction with safety and security, remains an essential promise for the aviation industry, even in the face of the economic downturn. IATA's vision is for carbon-neutral growth on the way to a zero-emission future. This is being implemented through IATA's four-pillar strategy: investing in technology, flying planes effectively, building efficient infrastructure and using positive economic measures (technology, operations, infrastructure and economic instruments). This paper will focus in the projection on biofuel as an alternative energy compromise reduction in carbon dioxide $\left(\mathrm{CO}_{2)}\right.$ emission in overview through short-term and long-term feedstock biomass. As environmental concerns are becoming clearer in general transportation systems, air transportation generates for its presence which must be considered in strategic planning development for the bio jet fuel to be implemented in near future in air transport operations for tenable greener skies.
\end{abstract}

\section{Introduction}

The contribution of aviation to the greenhouse gas (GHG) emission is approximately 2 to $3 \%$. According to ICAO this is going to increase about $15 \%$ by 2050 at this rate of pollutions [1]. Aviation has contributed to magnify the effects of pollution by directly affecting the ozone depletion in the upper reaches of the atmosphere. What is an impact of Aviation GHG?

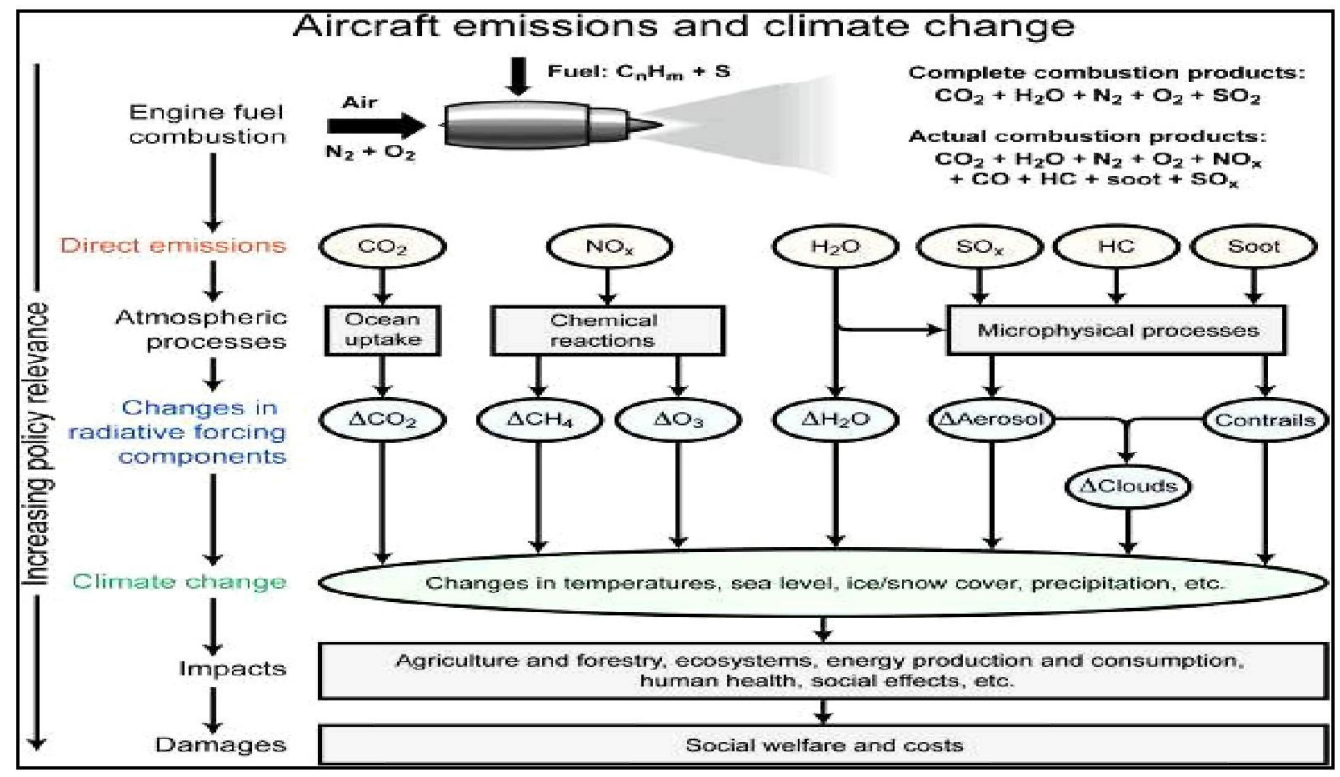

Fig. 1 Aircraft emissions and climate change adaptation from Wuebles [2]

Aviation climate impacts are due to both $\mathrm{CO}_{2}$ and non- $\mathrm{CO}_{2}$ emissions. The non- $\mathrm{CO}_{2}$ emissions include water vapor $\left(\mathrm{H}_{2} \mathrm{O}\right)$, nitrogen oxides $(\mathrm{NOx})$, sulfur oxides $(\mathrm{SOx})$, hydrocarbons $(\mathrm{HC})$, and black carbon (or soot) particles. Climate impacts of $\mathrm{CO}_{2}$ emissions are well characterized and are 
independent of source location due to its relatively long atmospheric lifetime. Aircraft engines produce emissions that are similar to other emissions produced by fossil fuel combustion. However, most of these emissions are released directly into the upper troposphere and lower stratospheres where they are believed to have a different impact on atmospheric composition as displays in the schematic of aircraft emissions and their resulting potential impacts on climate change and social welfare. Aviation $\mathrm{CO}_{2}, \mathrm{H}_{2} \mathrm{O}$ and soot emissions contribute directly to climate change with positive radioactive forcing (net warming) [2]

\section{Problem Statement}

Technology is changing from novel smart aircraft to advancement in power plant generation for better fuel efficiencies. Technology, operations, infrastructure and economic instruments was a layout from IATA four pillars to reduce $\mathrm{CO}_{2}$. A new form of Air Traffic Management (ATM) research and experiments conducted by Iberia Spanish Airlines has shown that a reduction of 6-12\% of fuel use can be achieved through this system [3]. Concentrating in Projection on Biofuel also will be an alternative energy compromise reduction in $\mathrm{CO}_{2}$ emission, moreover the continuously increasing in fuel price. The options is no longer an option, it is necessity to the future demand.

\section{Methodology}

An investigation into what is being done to limit $\mathrm{CO}_{2}$ emissions, while keeping flights safe, comfortable and accessible, exposes that technology, operations, and infrastructure mention, may all hold the key to reducing mankind's carbon footprint. As environmental concerns are becoming clearer in general transport systems, the data of the short-term and the long-term feedstock will prognosis the bio jet fuel in future.

\section{The Solutions - Bio Jet Fuel}

In World War II, feedstock such as coal, natural gas, bio oils and cellulose mater producing fuel and were widely used. This is the most pervasive methods of conversion includes reforming it through heat and catalytic reaction to syngas $\left(\mathrm{CO}\right.$ and $\left.\mathrm{H}_{2}\right)$. Later the scientist found that the plant derived fuel includes feedstock from soybean oils, palm oils, corn, algae, switch grass, etc. What is biofuel and what is biomass? Biofuel is fuel being produced out of biomass. While biomass is any renewable biological raw material such as plants, algae, waste etc. In the relation to Aircraft, we have bio jet fuel which, fuel being produced out of biomass and need to be developed especially for aviation applications. One of the challenges for bio jet fuel will be their properties to freeze at normal operating cruise temperatures, which is greater than normal biodiesel [4]. Other major challenges will be of pure bio jet fuel is its poor high temperature thermal stability characteristics in the engine. All these challenges are important, and the results have been substantially improved. Until today, all bio jet fuel is a 'blend' where by mixing of different types of fuel and current fuel specifications required bio jet fuel to be blend up to maximum of $50 \%$.

Biofuel Generation. Biofuel has been classified that often heard as "first generation' or 'second generation 'and sometimes even "third generation." Among all this three biofuel generation, the things that make it different are the final product of biofuel and the maturity of the science behind that fuel.

First Generation. First generation biofuels are defined as those conventionally produced from food crops. Unfortunately, first generation biofuels have withdrawn many disadvantages. They are being criticized for several reasons such as relatively low greenhouse gas (GHG) emissions avoidance, unsustainable production relating to deforestation, water use, and land management, competition for food crop feedstock's pushing up food commodity prices, and the need for generous government support schemes to remain competitive even after the technologies have become mature [5]. In addition, some of the first-generation biofuels, such as biodiesel and ethanol 
(produced from corn) are not suitable fuels for powering commercial aircraft. Many of these fuels don't meet the high performance or safety specifications for jet fuel [6]. As a result, a lot of hope has been placed on second-generation biofuels.

Second Generation. Second generation biofuels produced via biomass and waste exploitation have significantly improved greenhouse gas emissions and the fuel's carbon footprint, and have resulted in less environmental damage [1,7]. Each of this generation being analyzed and identified for Air transportation use in giving the potential to deliver in large quantities, for greener, clean and cheap fuel such as Jathropa and Camelina for the short term feedstock while algae and halophytes and as long-term feedstock. Never less the usage of this biomass can be located most of everywhere in the worldwide, including in the deserts and salt water (Fig. 2).

- Algae

- Jatropha

- Camelina

Circles indicate potential locations for bio fuel feedstock growth (indicative estimate)

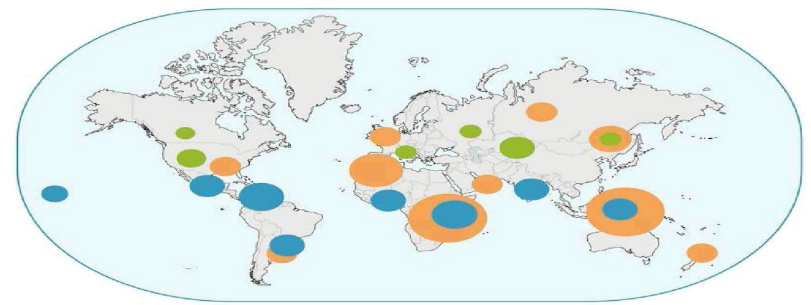

Fig. 2 Optimum land for growing sustainable aviation biofuels

Technology advancement will be crucial to determine the final results while logistic management will be varies especially for domestic usage. Some of the feedstock is better suited to some climates and locations where aviation will not rely only on one type of feedstock. With this second generation biofuel, it will have the potential to deliver large quantities of greener fuel for aviation at a more stable price.

\section{The Short-Term and Long-Term Feedstock of Bio Jet Fuel}

Jatropha-Crucas. Jatropha is seen by many to be the perfect biodiesel crop, but it's also being developed to fulfill the requirements for jet fuel. It can be grown in very poor soils actually generating top soil as it goes, is drought and pest resilient, and it has seeds with up to $40 \%$ oil content. It's required lots of water, tropical country will be perfect to grown this biomass. Jatropha biofuel has a relatively greater cetane number, approximately the same amount of energy but minus the sulfur as opposed to diesel [9]. In December 2008, a biofuel blend of 50:50 Jatropha and Jet A1 fuel was used to power one of the Air New Zealand Boeing 747-400's Rolls-Royce RB211 engines. The biofuel was responsible for a $1.2 \%$ savings in fuel over the 12-hour flight, which equaled 1.43 tonnes of fuel. The flight resulted in a $60-65 \%$ reduction in greenhouse gas emissions where scientists also estimate that the decrease in fuel consumption saved around 4.5 tonnes of $\mathrm{CO}_{2}$ emissions [10].

Camelina. Camelina or sometimes call false flax or gold-of-pleasure is primarily an energy crop, which have very high lipid oil content. Because Camelina needs little water or nitrogen to flourish, it can be grown on marginal agricultural lands. Camelina sativa originated in Europe and is a member of the mustard family, along with broccoli, cabbage and canola. Oil from Camelina can be converted to a hydrocarbon green jet fuel that meets or exceeds all petroleum jet fuel specifications [11]. With seed oil content in the range of $35-40 \%$ and even more $(45 \%)$ in some genotypes. The fuel is a 'drop-in' replacement that is compatible with the existing fuel infrastructure, from storage and transportation to aircraft fleet technology. In January 30th, 2009, Japan Airlines (JAL) became the first airline to conduct a demonstration flight using a sustainable biofuel primarily refined from Camelina. The biofuel component tested was a mixture of three second-generation biofuel feedstocks: Camelina (84\%), Jatropha (under 16\%), and algae (under 1\%) [12]. Like Jatropha, Camelina has certain limitations. The seeds are very small (1000 seeds weigh about $1 \mathrm{~g})$ and therefore require careful seedbed preparation before sowing to ensure proper crop emergence. 
Another issue is that there are no available herbicides for Camelina. However, this problem can be partially overcome by employing agricultural practices such as a high seeding rate and appropriate sowing time.

Halophytes. Accordingly to Glenn (2009), the most promising halophyte have found thus far is Salicornia bigelovii. It is a leafless, succulent, annual salt-marsh plant that colonizes new areas of mud flat through prolific seed production. The seeds contain high levels of oil $(30 \%)$ and protein ( $35 \%$ ), much like soybeans and other oilseed crops, and the salt content is less than $3 \%$. A small drawback is that the seed contains saponins, bitter compounds that make the raw seeds inedible. These do not contaminate the oil, but they can remain in the meal after oil extraction. During six years of field trials in Mexico, Salicornia produced an average annual crop of 1.7 kilograms per square meter of total biomass and 0.2 kilogram per square meter of oilseed. These yields equal or exceed the yields of soybeans and other oilseeds grown using freshwater irrigation $[10,11]$

Algae. Among all of the second generation biofuels, algae fuels have attracted most attention and have more optimistic solutions. If we are to produce the same amount of algae based fuel as we produce from the normal petroleum, the advantage is that the algae based system would consume approximately $13 \%$ Carbon dioxide of the production from Petroleum since, refer Fig. 3[14]:

$>$ Micro-algae are much more efficient converters of solar energy than any known plant, because they grow in suspension where they have unlimited access to water and more efficient access to $\mathrm{CO} 2$ and dissolved nutrients.

$>$ The total oil content in algae can be up to $70 \%$ of their dry weight.

$>$ Micro-algae are the fastest growing photosynthesizing organisms. They can complete an entire growing cycle every few days.

$>120$ tons of oil/hectare/year can be produced from algae.

$>$ Algae production can be increased by increasing the carbon dioxide concentration in the water.

$>$ One quad (1015 BTU or 7.5 billion gal.) of biodiesel could be produced on 200,000 ha of desert land (equivalent to 772 sq. mi., roughly 500,000 acres).

All of these points make the algae based biofuels more efficient in terms of carbon footprint. It can reduce the carbon foot print of the aviation industry by as much as $85 \%$. $13 \%$ is being saved on production, more than half during the engine operations and almost half in the transportation of fuel $[1,14]$. Put simply, micro algae are remarkable and efficient biological factories capable of taking a waste (zero-energy) form of carbon and converting it into a high density liquid form of energy (natural oil).

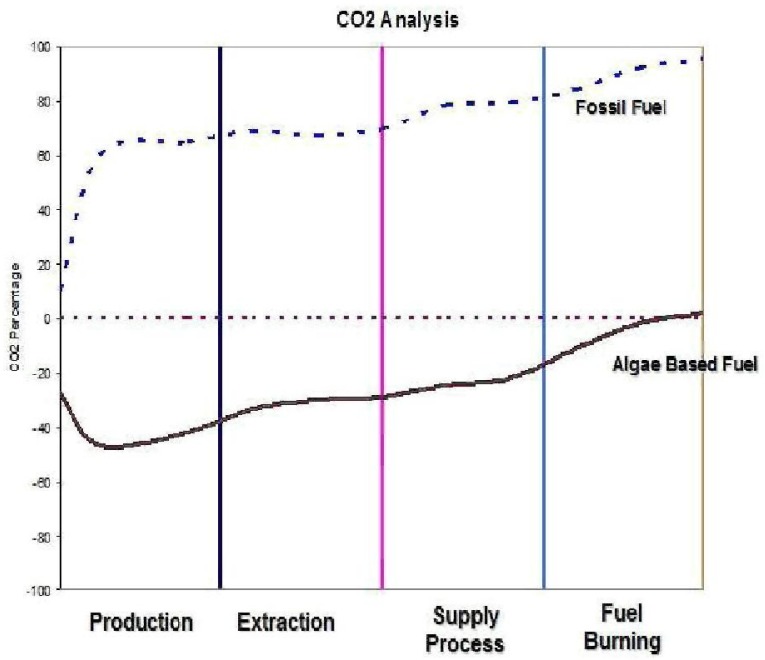

Fig. $3 \mathrm{CO}_{2}$ analysis of the algae biofuel cycle as a percentage of $\mathrm{CO}_{2}$ in the whole cycle with respect to fossil fuels 
Table 1: Summary on four main short-term and long-term feedstocks for biofuel

\begin{tabular}{|l|l|l|l|}
\hline \multicolumn{2}{|c|}{ SHORT TERM } & \multicolumn{2}{c|}{ LONG TERM } \\
\hline \multicolumn{1}{|c|}{ JATHROPA } & \multicolumn{1}{c|}{ CAMELINA } & \multicolumn{1}{c|}{ ALGAE } & \multicolumn{1}{c|}{ HALOPHYTES } \\
\hline Nonfood crop & Nonfood crop & Nonfood crop & High oil yield \\
\hline $\begin{array}{l}\text { 30 to } 40 \% \text { oil from each } \\
\text { mass of seed }\end{array}$ & Minimal inputs & $\begin{array}{l}15 \text { times more oil/ square } \\
\text { km than others }\end{array}$ & Hing \\
\hline $\begin{array}{l}\text { Grown in marginal land } \\
2 \text { to } 3 \text { years to get the } \\
\text { effective yielding }\end{array}$ & $\begin{array}{l}\text { Grown in marginal } \\
\text { land as a rotational } \\
\text { crop }\end{array}$ & $\begin{array}{l}\text { Grown in polluted/ salt } \\
\text { water, desert barren land }\end{array}$ & $\begin{array}{l}\text { Grown in barren } \\
\text { land }\end{array}$ \\
\hline $\begin{array}{l}\text { Residue are toxic for } \\
\text { both human and animal } \\
\text { fertilizer after treatment }\end{array}$ & animal feedstock & animal feedstock & $\begin{array}{l}\text { Residue can be } \\
\text { used as animal } \\
\text { feedstock }\end{array}$ \\
\hline
\end{tabular}

Table 2: Bio jet fuel flight test

\begin{tabular}{|c|c|c|c|c|c|}
\hline CARRIER & AIRCRAFT & PARTNERS & DATE & BIO-FUEL & BLEND \\
\hline $\begin{array}{l}\text { Virgin } \\
\text { Atlantic }\end{array}$ & B747-400 & $\begin{array}{l}\text { Boeing, GE } \\
\text { Aviation }\end{array}$ & 23.02 .2008 & $\begin{array}{l}\text { Coconut, } \\
\text { Babassu }\end{array}$ & $\begin{array}{l}20 \% \text { one } \\
\text { engine }\end{array}$ \\
\hline $\begin{array}{l}\text { Air New } \\
\text { Zealand }\end{array}$ & B747-400 & $\begin{array}{l}\text { Boeing, Roll } \\
\text { Royce }\end{array}$ & 30.12 .2008 & Jathropa & $\begin{array}{l}50 \% \text { one } \\
\text { engine }\end{array}$ \\
\hline $\begin{array}{l}\text { Continental } \\
\text { Airlines }\end{array}$ & B 737-800 & $\begin{array}{l}\text { Boeing, GE } \\
\text { Aviation, CFM, } \\
\text { Honeywell UOP }\end{array}$ & 7.01 .2009 & $\begin{array}{l}\text { Algae and } \\
\text { Jathropa }\end{array}$ & $\begin{array}{l}50 \% \text { one } \\
\text { engine }\end{array}$ \\
\hline JAL & B 747-300 & $\begin{array}{l}\text { Boeing, P\&W, } \\
\text { Honeywell UOP }\end{array}$ & 30.01 .2009 & $\begin{array}{l}\text { Camelina, } \\
\text { Jathropa, } \\
\text { Alage blend }\end{array}$ & $\begin{array}{l}50 \% \text { one } \\
\text { engine }\end{array}$ \\
\hline $\begin{array}{l}\text { QATAR } \\
\text { Airlines }\end{array}$ & A340-600 & Airbus, Shell & 12.10 .2009 & $\begin{array}{l}\text { Gas to Liquid } \\
\text { (Not biofuel) }\end{array}$ & $\begin{array}{l}50 \% \text { four } \\
\text { engine }\end{array}$ \\
\hline KLM & B747-400 & $\begin{array}{l}\text { GE, Honeywell } \\
\text { UOP }\end{array}$ & 23.11 .2009 & Camelina & $\begin{array}{l}50 \% \text { one } \\
\text { engine }\end{array}$ \\
\hline United & A319 & Rentech & 30.04 .2010 & GTL & $\begin{array}{l}40 \% \text { two } \\
\text { engine }\end{array}$ \\
\hline $\begin{array}{l}\text { TAM } \\
\text { Airlines }\end{array}$ & A 320 & Airbus, CFM & 23.11 .2010 & Jathropa & $50 \%$ \\
\hline Interjet & A320 & $\begin{array}{l}\text { CFM, SAfran, } \\
\text { EADS, }\end{array}$ & 1.04 .2011 & Jathropa, & $50 \%$ \\
\hline Lufthansa & A321 & $\begin{array}{l}\text { Airbus, Lufthansa } \\
\text { Technik (LHT) } \\
\text { and MTU Aero } \\
\text { Engines }\end{array}$ & $\begin{array}{l}15 \text { July }-27 \\
\text { December } \\
2011\end{array}$ & $\begin{array}{l}\text { Jathropa, } \\
\text { Camelina, } \\
\text { Animal fat }\end{array}$ & $\begin{array}{l}50 \% \text { of one } \\
\text { engine }\end{array}$ \\
\hline $\begin{array}{l}\text { Air China } \\
\text { (CA) }\end{array}$ & B747-400 & $\begin{array}{l}\text { Boeing, Petro } \\
\text { China, } \\
\text { HoneywellUOP }\end{array}$ & June 2011 & Jathropa & $\begin{array}{l}50 \% \text { of one } \\
\text { engine }\end{array}$ \\
\hline KLM & B737-800 & KLM, SyNRG & 29.06 .2011 & Cooking oil & $\begin{array}{l}50 \% \text { of one } \\
\text { engine }\end{array}$ \\
\hline Iberia & A320 & $\begin{array}{l}\text { Aibus, Iberia, } \\
\text { SkyNRG }\end{array}$ & 03.10 .2011 & Camelina & $\begin{array}{l}25 \% \text { of one } \\
\text { engine }\end{array}$ \\
\hline $\begin{array}{l}\text { Porter } \\
\text { airlines PD }\end{array}$ & $\begin{array}{l}\text { Q 400 } \\
\text { Bombardier }\end{array}$ & $\begin{array}{l}\text { P\&W, } \\
\text { HoneywellUOP }\end{array}$ & 18.04 .2012 & $\begin{array}{l}\text { Oilseed, } \\
\text { Camelina } \\
\text { sativa and } \\
\text { Brassica } \\
\text { carinata }\end{array}$ & $\begin{array}{l}50 \% \text { of one } \\
\text { engine }\end{array}$ \\
\hline
\end{tabular}




\section{Conclusions and Recommendations}

The primary benefit of using biofuels in a commercial jetliner is their ability to reduce greenhouse gases throughout their entire lifecycle, while also helping to improve the environmental performance of commercial aviation and the planes that are flying today. The technical certification and sustainability of new fuels need to ensuring bio jet fuel can be dropped in to existing common fueling infrastructure with simple harmonized bio jet accounting and reporting procedures and best practices for bio jet purchase and insurance, so in terms of cost competitiveness aviation players can pursue affordable bio jet solutions for better greener skies. Table 2 shows some of the bio jet fuel flight test being conducted that proven most of it were using Jatropha, Camelina or Algae as its bio jet fuel.

\section{References}

[1] IATA Report on Alternative Fuels 2007, Feb 2008, Dec.2009, Dec. 2010.

[2] ICAO Environmental Report 2007, 2008, 2009, 2010

[3] Stevens D. J., J. Worgetten \& J. Saddler. (2004). Biofuels for transportation: an examination of policy and technical issues (Final report No. IEA Bioenergy task 39).

[4] Lee, D.S., G. Pitari, V. Grewe et al. (2010), Transport impacts on atmosphere and climate: Aviation. Atmospheric Environment 44(37), pp.4678-4734.

[5] D.; Hendricks, R.; and Walther, R.: 2007 Daggett, Alternative Fuels and Their Potential Impact on Aviation. NASA/TM-2006-214365 (ICAS 2006-5.8.2),

[6] Weaver, P., Jansen, L., Van Grootveld, G., Van Spiegel, E. \& Vergragt, P. (2000). Sustainable Technology Development. Sheffield UK: Greenleaf

[7] L.Q. Maurice*, H. Lander1, T. Edwards, W.E. Harrison Advanced aviation fuels: a look ahead via a historical perspective.

[8] Nielson, Dave; and Daggett, Dave: Aircraft Alternate Fuels. Presented to Transportation Research Board, Washington, DC.

[9] European Journal of Scientific Research ISSN 1450-216X Vol.29 No.3 (2009), pp.396-403 Characteristic and Composition of Jatropha Curcas Oil Seed from Malaysia

[10] Air New Zealand flight test http://www.businessgreen.com/bg/news/1807221/air- newzealand-declares-jatropha-biofuel-flight-success

[11] A. Fröhlich,B. RiceTeagasc Evaluation of Camelina sativa oil as a feedstock for biodiesel production, Crops Research Centre, Oak Park, Carlow, Co. Carlow, Ireland Received 10 December 2002. JAL biofuel flight test http://press.jal.co.jp/en/release/200901/001108.html

[12] Edward P. Glenn and J. Jed Brown Salt Tolerance and Crop Potential of Halophytes

[13] EUR Biodiesel from Algae, National Renewable Energy Laboratory (U.S.A.); NREL/ TP-58024190.

[14] M.N.Hazariah, R. Adeel, S.N Sujith, G.Peter, ICET2009 Kuala Lumpur,A BUSINESS MODEL- A NEW GLOBAL ENERGY SYSTEM FOR AEROSPACE 


\section{AEROTECH IV}

10.4028/www.scientific.net/AMM.225

Short-Term and Long-Term Feedstock Bio Jet Fuel for Green Environment of Air Transport in Climate Change Awareness

10.4028/www.scientific.net/AMM.225.572 